\title{
PENGARUH MODEL NUMBER HEAD TOGETHER (NHT) BERBANTU MEDIA MONOPOLI UNTUK MENINGKATKAN HASIL BELAJAR DAN KEMAMPUAN BERPIKIR KREATIF SISWA KELAS IV SUBTEMA HEBATNYA CITA-CITAKU SDN MRANGGEN 04
}

\author{
Latifatul Ariyani ${ }^{1}$, Fenny Roshayanti ${ }^{2}$, Sunan Baedowi ${ }^{3}$ \\ 1,2,3 Jurusan Pendidikan Guru Sekolah Dasar \\ Universitas Pendidikan Ganesha \\ Singaraja, Indonesia \\ e-mail: Latifatulariyani9@gmail.com
}

\begin{abstract}
Abstrak
Jenis penelitian ini adalah penelitian kuantitatif dalam bentuk Quasi Eksperimental dengan desain Nonequivalent Control Group Design. Tujuan yang hendak dicapai dalam penelitian ini adalah untuk mengetahui pengaruh model pembelajaran Numbered Heads Together (NHT) dengan pada hasil belajar dan kemampuan berpikir kreatif siswa kelas IV SDN MRANGGEN 04 yang dilihat pada hasil belajar dan kemampuan berpikir kreatif. Populasi penelitian adalah seluruh siswa kelas IV SDN MRANGGEN 04 tahun pelajaran 2019. Sampel yang diambil adalah 41 siswa kelas IVA dan IVB teknik Probability Sampling berbentuk Cluster Sampling. Data dalam penelitian ini diperoleh melalui tes, wawancara, dokumentasi, dan observasi. Hasil analisis pretest dan posttest pada hasil belajar siswa menggunakan uji $t$ didapatkan $t_{\text {hitung }}=2,3539$ dengan $t_{\text {tabel }}=$ 2,0243. Untuk $\mathrm{H}_{0}$ diterima jika $t_{\text {hitung }} \geq t_{\text {tabel }}$ karena $t_{\text {hitung }}=2,3539>t_{\text {tabel }}=2,0243$ maka $H_{0}$ diterima dan $\mathrm{H}_{\mathrm{a}}$ ditolak. Hal ini berarti bahwa ada perbedaan hasil belajar siswa yang signifikan antara rata-rata hasil belajar setelah perlakuan di kelas eksperimen dan kelas kontrol. Sementara itu, hasil perhitungan hipotesis kemampuan berpikir kreatif siswa dengan menggunakan uji t didapatkan $t_{\text {hitung }}=2,5115$ dengan $t_{\text {tabel }}=2,0243$. . Untuk $\mathrm{H}_{0}$ diterima jika $t_{\text {hitung }} \geq t_{\text {tabel }}$ karena $t_{\text {hitung }}=2,5115>t_{\text {tabel }}=2,0243$ maka $\mathrm{H}_{0}$ diterima dan $\mathrm{H}_{\mathrm{a}}$ ditolak. Hal ini berarti bahwa ada perbedaan kemampuan berpikir kreatif siswa yang signifikan antara hasil tes setelah perlakuan di kelas eksperimen dan kelas kontrol.
\end{abstract}

Kata-kata kunci : Number Head Together (NHT), Media Monopoli

\begin{abstract}
The type of this research is quantitative research in the form of Quasi Experimental with Nonequivalent Control Group Design Sampling techniques in the form of cluster sampling. The objective to be achieved in this study is to determine the effect of the Numbered Heads Together (NHT)with learning model on learning outcomes and the creative thinking ability of grade IV SDN MRANGGEN 04 students seen in learning outcomes and creative thinking abilities. The sample taken was 41 students of IVA and IVB probability. The data in this study were obtained through test, interviews, documentations and observation.The results of the pretest and posttest analysis on student learning outcomes using the $t_{\text {test }}$ obtained $t_{\text {count }}=2.3539$ with $t_{\text {table }}=2.0243$. For $\mathrm{H}_{0}$ is accepted if $\mathrm{t}_{\text {count }} \geq$ ttable because tcount $=2.3539>$ ttable $=2.0243$ then $\mathrm{HO}$ is accepted and $\mathrm{Ha}$ is rejected. This means that there are significant differences in student learning outcomes between the average learning outcomes after treatment in the experimental class and the control class. Meanwhile, the results of calculating the hypothesis of students' creative thinking abilities using the $t$ test obtained $t_{\text {count }}=2.5115$ with $t_{\text {table }}=2.0243$. For $H_{0}$ is accepted if $t_{\text {count }} \geq t_{\text {table }}$ because $t_{\text {count }}=2.5115>t_{\text {table }}=$ 2.0243 then $\mathrm{H}_{0}$ is accepted and $\mathrm{Ha}$ is rejected. This means that there are significant differences in students creative thinking abilities between test results after treatment in the experimental class and the control class.
\end{abstract}

Keywords: Number Head Together (NHT), Creative Thingking Skills, Monopoly Media 


\section{Pendahuluan}

Pendidikan merupakan suatu komponen dalam kehidupan manusia yang paling penting. Pendidikan sendiri mulai berproses sejak manusia lahir di dunia. Pendidikan dibawa oleh manusia terdahulu dan diajarkan kepada kita hingga saat ini. Dengan pendidikan manusia dapat mengetahui berbagai hal yang sebelumnya tidak diketahui. Tanpa adanya pendidikan manusia tidak dapat mengetahui apa-apa. Oleh karena itu pemerintah berupaya dengan didirikannya sekolah-sekolah dimana dalam sekolah tersebut menjadi sarana untuk dilaksanakannya sebuah pendidikan.

Menurut Undang-undang Sistem Pendidikn Nasional Undang-Undang No. 20 tahun 2013, pendidikan adalah usaha sadar dan terencana untuk mewujudkan suasana belajar dan proses pembelajaran agar siswa secara aktif mengembangkan potensi dirinya untuk memiliki kekuatan spiritual keagamaan, pengendalian diri, kepribadian, kecerdasan, akhlak mulia, serta ketrampilan yang di perlukan dirinya, masyarakat, bangsa, dan Negara. Hal ini berarti bahwa tujuan dalam pendidikan bukan hanya pada aspek masa kini melainkan juga pembentukan sumber daya manusia yang memiliki kemampuan berpikir kratif dan berkualitas melalui pendidikan yang dilakukan secara bersungguh-sungguh dan terus menerus.

Kreatifitas merupakan suatu potensi yang dimiliki oleh setiap manusia dengan kemampuan mental dan memiliki berbagai keterampilan khas yang dapat Memunculkan hasilhasil baru. Oleh karena itu upaya untuk mengembangkan kreatifitas siswa perlu di lakukan. Karena kita peneliti merupakan calon seorang pendidik yang dimana tugas kita nanti adalah menciptakan seseorang yang tidak hanya berkualitas dan berkarakter namun juga seorang yang memiliki kreatifitas sehingga kedepannya dapat memiliki pandangan yang luas untuk menjadikan siswa lebih menciptakan ide-ide baru yang bermanfaat untuk kedepannya.

Hasil Progress in International Reading Literacy Study (PIRLS) tahun 2012 menempatkan siswa kelas IV Indonesia di urutan ke-42 dari 45 negara dengan skor 428 . Permasalahan terkait Rendahnya kemampuan siswa Indonesia di matematika, sains, dan membaca juga tercermin dalam Programe for International Student Assessment (PISA) yang dilaporkan Kompas (2012) mengukur kecakapan anak berusia 15 tahun dalam mengimplementasikan pengetahuan yang dimilikinya untuk menyelesaikan permasalahan merupakan hasil yang sangat memprihatinkan. Berdasarkan hasil observasi dan wawancara yang dilakukan di SDN Mranggen 04 dengan Ibu Vina yang mengajar di kelas IVA yang digunakan sebagai kelas eksperimen ditemukan beberapa masalah yang terkait dengan adanya penerapan kurikulum 2013. Pada kurikulum 2013 siswa masih banyak yang belum bisa mengikuti pembelajaran yang ada dikarenakan beberapa siswa belum paham dengan materi yang diajarkan menggunakan model pembelajaran yang konvensional. Akibatnya siswa cenderung pasif pada saat pembelajaran berlangsung. Hal tersebut membuat siswa tidak bisa mengikuti proses pembelajaran dengan baik. Selain itu guru masih kurang dalam pemanfaatan model pembelajaran dan media yang digunakan dalam pembelajaran. Sehingga siswa kurang tertarik dan semangat dalam menanggapi materi pembelajaran. Pada penelitian ini akan menerapkan model pembelajaran Numbered Heads Together (NHT) dengan menggunakan media Monopoli sebagai alat bantunya.

Model pembelajaran yang diterapkan merupakan sebuah model pembelajaran yang dijadikan solusi dalam permasalahan yang ditemukan. Huda (2014: 143) model pembelajaran harus dianggap sebagai kerangka kerja struktural yang juga dapat digunakan sebagai pemandu untuk mengambangkan lingkungan dan aktivitas belajar yang kondusif. Karena Menurut Shoimin (2014:108) NHT merupakan model pembelajaran berkelompok yang setiap anggota kelompoknya bertanggung jawab atas tugas kelompoknya, sehingga tidak ada pemisahan antara siswa yang satu dengan yang lain dalam satu kelompok untuk saling memberi dan menerima antara satu dan yang lain. Dengan menggunakan model pembelajaran Numbered Heads Together (NHT) ini siswa juga dapat saling menukar pendapat yang dimiliki dalam sebuah diskusi kelompok. Dalam kegiatan tukar pendapat tersebut akan memunculkan interaksi untuk mencapai suatu tujuan yang melibatkan kerjasama dalam sebuah kelompok. 
Dengan menggunakan model Numbered Heads Together (NHT) yang melibatkan siswa secara keseluruhan. Diharapkan supaya seluruh siswa dapat aktif, penelitian ini juga dibantu dengan media Monopoli. Media monopoli digunakan sebagai inovasi pembelajaran. Dengan menggunakan media monopoli ini akan membantu mengubah cara guru dalam menerangkan pembelajaran pada siswa yang dirasa monoton dan membosankan. Alasan mengapa media monopoli digunakan karena media ini merupakan permainan anak yang sudah banyak dijumpai yang dimainkan dengan menggunakan dadu dan mudah untuk dimainkan. Banyak sekali jenis media, namun media monopoli yang akan saya gunakan ini diharapkan dapat meningkatkan hasil belajar dan kreatifitas siswa pada proses kegiatan pembelajaran.

Tujuan penelitian ini adalah untuk mengetahui pengaruh dari Model Pembelajaran Numbered Heads Together (NHT) berbantu media monopoli terhadap hasil belajar dan kemampuan berpikir kreatif siswa subtema hebatnya cita-citaku kelas IV Sekolah Dasar.

\section{Metode}

Metode yang digunakan penulis dalam penelitian ini adalah metode eksperimen semu (Quasi Eksperiment. Menurut Sugiyono (2015: 114), "bentuk desain eksperimen ini merupakan pengembangan dari true eksperimental design, yang sulit dilaksanakan. Desain ini mempunyai kelompok kontrol, tetapi tidak dapat berfungsi sepenuhnya untuk mengontrol variabel-variabel luar yang mempengaruhi pelaksanaan eksperimen. Quasi eksperimental design digunakan karena pada kenyataannya sulit mendapatkan kelompok kontrol yang digunakan dalam penelitian. Penelitian ini merupakan penelitian pretest-posttest control group design, yaitu dengan kelompok eksperimen maupun kelompok kontrol tidak dipilih secara random. Desain penelitiannya digambarkan sebagai berikut :

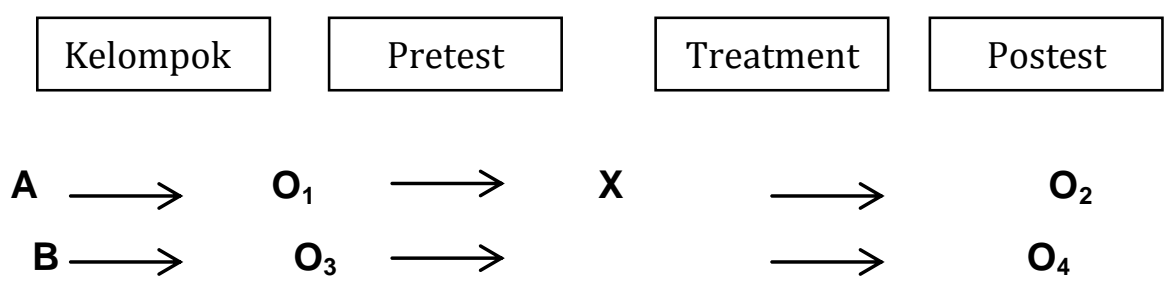

(Sugiyono, 2015: 112)

Gambar 1. Desain penelitian pretest-posttest control group design

Keterangan :
$A=$ Kelompok Eksperimen
$\mathrm{B}=$ Kelompok Kontrol
$\mathrm{O}_{1}=$ Test sebelum diberi perlakuan kelas eksperimen
$\mathrm{O}_{2}=$ test setelah diberi perlakuan kelas eksperimen
$\mathrm{O}_{3}=$ tes sebelum pembelajaran tanpa perlakuan kelas kontrol
$\mathrm{O}_{4}=$ test setelah pembelajaran tanpa perlakuan kelas kontrol
$\mathrm{X}=$ pembelajaran dengan menggunakan model NHT berbantu media monopoli

Dari desain tersebut dapat dilihat bahwa kedua kelompok yakni kelompok eksperimen (A) dan kelompok kontrol (B) diawal mendapatkan perlakuan sama yaitu pretest. Selanjutnya untuk kelompok eksperimen diberikan perlakuan menggunakan model pembelajaran Numbered Heads Together (NHT) berbantu media monopoli. Sedangkan pada waktu yang bersamaan kelompok kontrol tidak mendapatkan perlakuan yang sama dengan pembelajaran yang dilakukan di kelas eksperimen. Pembelajaran pada kelompok kontrol masih sama dengan pembelajaran sebelumnya yakni tanpa adanya pemberian perlakuan. Terakhir, kedua 
kelompok mendapatkan perlakuan yang sama kembali, yakni postest untuk melihat hasil akhir apakah terdapat perbedaan yang signifikan atau tidak.

\section{Hasil dan Pembahasan}

Data dalam penelitian terdiri dari dua macam yaitu pretest dan postest. Pretest diambil dari nilai pretest kelas eksperimen dan kelas kontrol sebelum pemberian perlakuan. Sementara itu postest diambil dari nilai postest kelas eksperimen dan kelas kontrol setelah mendapat perlakuan. Data awal pretest digunakan untuk melihat hasil belajar siswa sebelum diberikan perlakuan. Nilai ini dijadikan patokan pada kemampuan awal siswa kelas IV SDN Mranggen 04.

Tabel 1. Kategori Nilai Pretest dan Postest Hasil Belajar

\begin{tabular}{|c|c|c|c|c|c|c|c|c|c|c|}
\hline \multirow[b]{3}{*}{ No } & \multirow[b]{3}{*}{ Interval } & \multirow[b]{3}{*}{ Kategori } & \multicolumn{4}{|c|}{ Pretest } & \multicolumn{4}{|c|}{ Postest } \\
\hline & & & \multicolumn{2}{|c|}{ Eksperimen } & \multicolumn{2}{|c|}{ Kontrol } & \multicolumn{2}{|c|}{ Eksperimen } & \multicolumn{2}{|c|}{ Kontrol } \\
\hline & & & $\mathbf{F}$ & $\%$ & $\mathbf{F}$ & $\%$ & $\mathbf{F}$ & $\%$ & $\mathbf{F}$ & $\%$ \\
\hline 1 & $81-100$ & $\begin{array}{l}\text { Sangat } \\
\text { Tinggi }\end{array}$ & 0 & 0 & 0 & 0 & 13 & 65 & 8 & 40 \\
\hline 2 & $76-80$ & $\begin{array}{l}\text { Sangat } \\
\text { Tingai }\end{array}$ & 3 & 10 & 5 & 25 & 4 & 20 & 6 & 30 \\
\hline 3 & $71-75$ & Tinggi & 3 & 15 & 2 & 10 & 3 & 15 & 2 & 10 \\
\hline 4 & $66-70$ & Tinggi & 4 & 0 & 1 & 5 & 0 & 0 & 2 & 10 \\
\hline 5 & $61-65$ & Rendah & 5 & 25 & 2 & 10 & 0 & 0 & 2 & 10 \\
\hline 6 & $56-60$ & Rendah & 0 & 20 & 2 & 10 & 0 & 0 & 0 & 0 \\
\hline 7 & $51-55$ & Rendah & 3 & 15 & 2 & 10 & 0 & 0 & 0 & 0 \\
\hline 8 & $46-50$ & Rendah & 2 & 15 & 6 & 30 & 0 & 0 & 0 & 0 \\
\hline & Jumlah & & 20 & 100 & 20 & 100 & 20 & 100 & 20 & 100 \\
\hline
\end{tabular}

Hasil analisis deskriptif dapat dilihat pada Tabel pada Hasil analisis deskriptif dapat dilihat pada Tabel 2.

Tabel 2. Hasil Analisis Deskriptif Statistik Pretest dan Postest Hasil Belajar

\begin{tabular}{lllll}
\hline & N & Mean & Minimum & Maximum \\
\hline Pretest & & & & \\
Eksperimen & 20 & 65,75 & 30 & 90 \\
Kontrol & 20 & 66,5 & 40 & 90 \\
Postest & & & & \\
Eksperimen & 20 & 82,8 & 72 & 90 \\
Kontrol & 20 & 76,4 & 60 & 90 \\
\hline
\end{tabular}


Berdasarkan Tabel 2. menunjukkan hasil belajar Pretest siswa dapat ditunjukkan dalam bentuk diagram sebagai berikut:

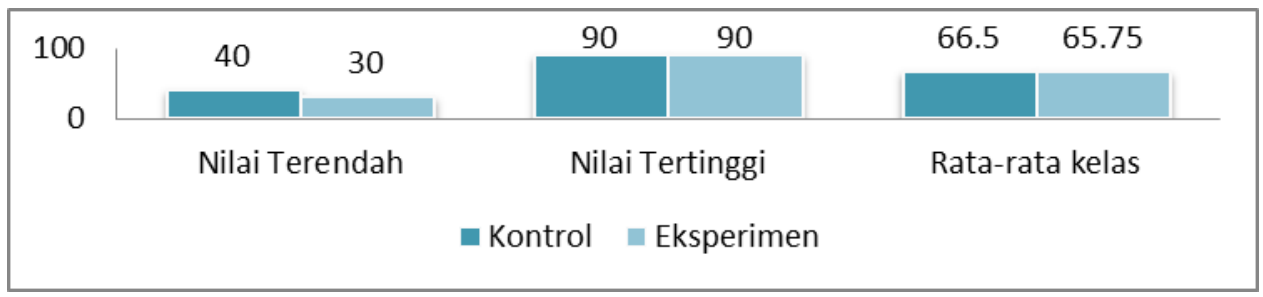

Gambar 2. Diagram Hasil Belajar Pretest Siswa Kelas Eksperimen dan Kelas Kontrol

Sedangkan hasil belajar posttest setelah mendapatkan perlakuan model pembelajaran Numbered Heads Together (NHT) berbantu media monopoli ditunjukkan dalam bentuk diagram sebagai berikut:

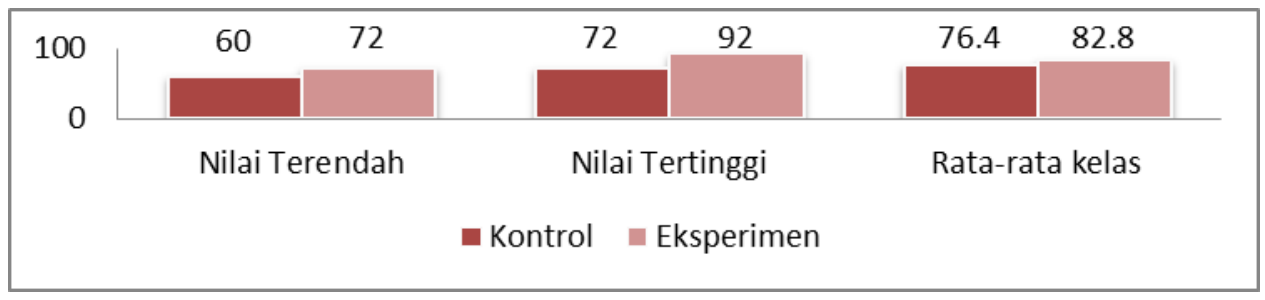

\section{Gambar 3. Diagram Hasil Belajar Posttest Siswa}

Ketuntasan belajar siswa dinyatakan jika siswa sudah mencapai batas KKM yang telah ditentukan yaitu 70. Berikut tabel ketuntasan belajar siswa berdasarkan nilai posttest:

Tabel 3. Ketuntasan Belajar Kelas Eksperimen dan Kelas Kontrol

\begin{tabular}{cccc}
\hline No & Hasil Belajar & Siswa & Ketuntasan Belajar Presentase Klasikal \\
\hline 1. & Kontrol & 16 & $80 \%$ \\
2. & Eksperimen & 20 & $100 \%$ \\
\hline
\end{tabular}

Berdasarkan Tabel 3. dapat diketahui bahwa ketuntasan individu pada kelas kontrol terdapat 16 siswa yang tuntas setelah menggunakan model pembelajaran Numbered Heads Together (NHT) dari 20 siswa dengan ketuntasan klasikal 80\%. Sedangkan pada kelas eksperimen terdapat 20 siswa yang tuntas setelahdengan ketuntasan klasikal $100 \%$. Ketuntasan belajar siswa kelas kontrol dan kelas eksperimen dapaat digambarkan kedalam diagram batang 4.2 berikut ini.

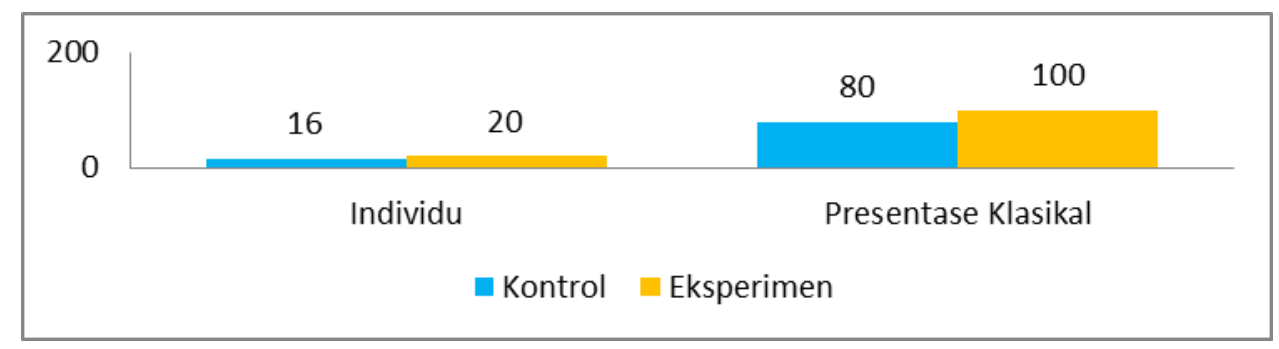

Gambar 4. Diagram Ketuntasan Belajar Siswa Kelas Eksperimen dan Kelas Kontrol 
Skor kemampuan berpikir kreatif baik kelas eksperimen maupun kelas kontrol dapat dilihat pada Tabel 4.

Tabel 4. Kategori Skor Kemampuan Berpikir

\begin{tabular}{clccccc}
\hline \multirow{2}{*}{ Indikator } & \multirow{2}{*}{ Kategori } & \multirow{2}{*}{ Interval } & \multicolumn{2}{c}{ Kelas Kontrol } & \multicolumn{2}{c}{ Kelas Eksperimen } \\
\cline { 3 - 6 } & & Frekuensi & $\%$ & Frekuansi & $\%$ \\
\hline \multirow{5}{*}{ Fluency } & Tinggi & $12 \mathrm{~s} / \mathrm{d} \geq 14$ & 3 & 15 & 7 & 35 \\
& Sedang & $6-11$ & 17 & 85 & 13 & 65 \\
& Rendah & $0-5$ & 0 & 0 & 0 & 0 \\
Flexibility & Tinggi & $12 \mathrm{~s} / \mathrm{d} \geq 14$ & 20 & 100 & 20 & 100 \\
& Sedang & $6-11$ & 0 & 0 & 0 & 0 \\
& Rendah & $0-5$ & 0 & 0 & 0 & 0 \\
Originality & Tinggi & $12 \mathrm{~s} / \mathrm{d} \geq 14$ & 3 & 15 & 6 & 30 \\
& Sedang & $6-11$ & 16 & 80 & 14 & 70 \\
& Rendah & $0-5$ & 1 & 5 & 0 & 0 \\
\multirow{5}{*}{ Evaluatuation } & Tinggi & $12 \mathrm{~s} / \mathrm{d} \geq 14$ & 4 & 20 & 2 & 10 \\
& Sedang & $6-11$ & 16 & 80 & 18 & 90 \\
& Rendah & $0-5$ & 0 & 0 & 0 & 0 \\
& Tinggi & $12 \mathrm{~s} / \mathrm{d} \geq 14$ & 20 & 100 & 20 & 100 \\
& Sedang & $6-11$ & 0 & 0 & 0 & 0 \\
& Rendah & $0-5$ & 0 & 0 & 0 & 0 \\
\hline
\end{tabular}

Tabel 5. Kemampuan Berpikir Kreatif Kategori Tinggi

\begin{tabular}{lclc}
\hline \multicolumn{1}{c}{ Kelas } & Rata-rata & Indikator & Rata-rata \\
\hline Eksperimen & 77,55 & Fluency & 10,65 \\
& & Flexibility & 18,3 \\
& & Originality & 10,25 \\
& & Elaboration & 9,65 \\
Kontrol & \multirow{2}{*}{71,15} & Evaluation & 21,3 \\
& & Fluency & 9,6 \\
& & Flexibility & 15,9 \\
& & Originality & 9,75 \\
& & Elaboration & 9,35 \\
& & Evaluation & 19,75 \\
\hline
\end{tabular}

Hasil analisis deskriptif dapat dilihat pada tabel tes kemampuan berpikir kreatif pada Tabel 5 berikut ini.

Tabel 5. Hasil Analisis Deskriptif Statistik Setelah Perlakuan Kemampuan Berpikir Kreatif

\begin{tabular}{lllcc}
\hline & N & Mean & Minimum & Maximum \\
\hline Eksperimen & 20 & 77,55 & 55 & 91 \\
Kontrol & 20 & 71,15 & 53 & 88 \\
\hline
\end{tabular}

Berdasarkan Tabel 5. tersebut hasil skor kemampuan berpikir kreaif setelah mendapatkan perlakuan menggunakan model pembelajaran Numbered Heads Together (NHT) siswa kelas eksperimen dan kelas kontrol dapat ditunjukkan dalam bentuk diagram sebagai berikut. 


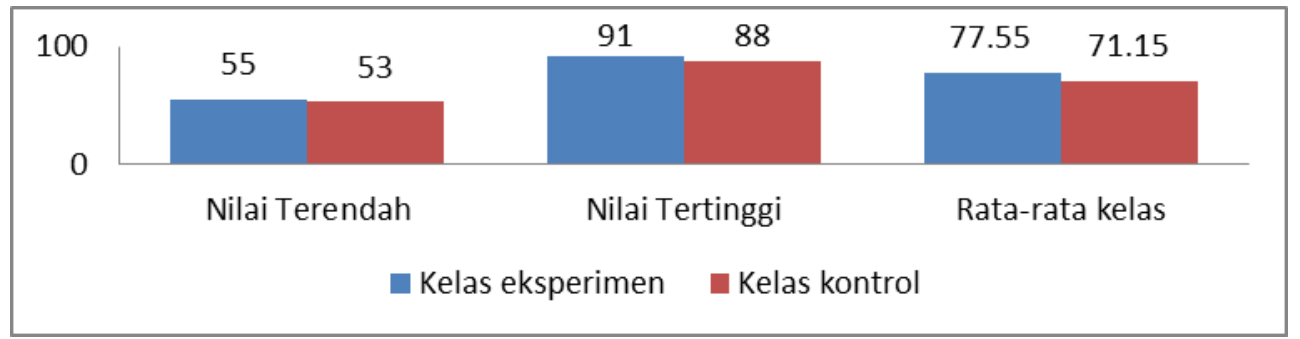

Gambar 5. Diagram Hasil Skor Kemampuan

Berdasarkan hasil analisis nilai kelas eksperimen dan kelas kontrol dari nilai awal dan nilai akhir terdapat perbedaan rata-rata hasil pembelajaran kelas yang mendapatkan perlakuan menggunakan model Numbered Heads Together (NHT) berbantu media monopoli dengan kelas yang tidak mendapatkan perlakuan sehingga dapat disimpulkan bahwa kelas yang mendapat perlakuan mendapatkan hasil yang lebih baik.

\section{A. Uji Persyaratan Analisis Data}

1. Analisis Data Awal

Penyajian hasil uji normalitas hasil belajar awal (pretest) kelas eksperimen dan kelas kontol dapat dilihat pada Tabel 6. berikut ini.

Tabel 6. Uji Normalitas Hasil Belajar Awal (Pretest)

\begin{tabular}{|c|c|c|c|c|}
\hline \multicolumn{5}{|c|}{ Pretest } \\
\hline No & Kelas & $L_{0}$ & $\mathbf{L}_{\text {tabel }}$ & Keterangan \\
\hline 1 & Eksperimen & 0,102 & 0,190 & Normal \\
\hline 2 & Kontrol & 0,166 & 0,190 & Normal \\
\hline
\end{tabular}

\section{Uji Normalitas Pada Hasil Belajar Akhir (Posttest)}

Secara umum, penyajian hasil uji normalitas hasil belajar akhir (posttest) kelas eksperimen dan kelas kontrol dapat dilihat pada Tabel 7. berikut ini.

Tabel 7. Uji Normalitas Hasil Belajar Akhir (Posttest) Kelas Eksperimen dan Kelas Kontrol

\begin{tabular}{ccccc}
\hline \multicolumn{5}{c}{ Postest } \\
\hline No & Kelas & $\mathbf{L}_{0}$ & $\mathbf{L}_{\text {tabel }}$ & Keterangan \\
\hline 1 & Eksperimen & 0,167 & 0,190 & Normal \\
2 & Kontrol & 0,134 & 0,190 & Normal \\
\hline
\end{tabular}

3. Analisis Data Akhir

a. Uji $t_{\text {test }}$ Hasil Belajar

1) Uji $t_{\text {test }}$ pretest Sebelum Perlakuan Kelas Eksperimen dan Kelas Kontrol. Berikut hasil perhitungan uji $t_{\text {test }}$ pretest kelas eksperimen dan kelas kontrol.

Tabel 8. Uji t Pretest Kelas Eksperimen dan Kelas Kontrol

\begin{tabular}{cccccc}
\hline $\begin{array}{c}\text { Mean } \\
\text { Eksperimen }\end{array}$ & $\begin{array}{c}\text { Mean } \\
\text { Kontrol }\end{array}$ & $\mathbf{t}_{\text {hitung }}$ & $\mathbf{t}_{\text {tabel }}$ & Kriteria & Ket \\
\hline $\mathbf{6 5 , 7 5}$ & 66,50 & 0,2895 & 2,0243 & $\mathrm{t}_{\text {hitung }}<\mathrm{t}_{\text {tabel }}$ & $\mathrm{H}_{0}$ diterima \\
\hline
\end{tabular}


2) Uji $t_{\text {test }}$ pretest dan postest Kelas Kontrol. Berikut ini hasil perhitungan uji test pretest dan posttest kelas kontrol

Tabel 9. Uji t Pretest dan Posttest kelas Kontrol

\begin{tabular}{cccccc}
\hline Pretest & Posttest & $\mathbf{t}_{\text {hitung }}$ & $\mathbf{t}_{\text {tabel }}$ & Kriteria & Ket \\
\hline 66,50 & 76,40 & 3,6761 & 2,0243 & $t_{\text {hitung }}<t_{\text {tabel }}$ & $\mathrm{H}_{0}$ diterima \\
\hline
\end{tabular}

3) Uji $t_{\text {test }}$ Pretest dan Posttest Kelas Eksperimen. Berikut ini hasil perhitungan uji $t_{\text {test }}$ pretest dan posttest kelas Eksperimen.

Tabel 10. Uji $t_{\text {test }}$ Pretest dan Posttest Kelas Eksperimen

\begin{tabular}{cccccc}
\hline Pretest & Posttest & $\mathbf{t}_{\text {hitung }}$ & $\mathbf{t}_{\text {tabel }}$ & Kriteria & Ket \\
\hline 65,75 & 82,80 & 6,2090 & 2,0243 & $t_{\text {hitung }}>t_{\text {tabel }}$ & $\mathrm{H}_{0}$ ditolak \\
\hline
\end{tabular}

4) Uji $t_{\text {test }}$ Posttest Kelas Eksperimen dan Kelas Kontrol. Berikut ini hasil perhitungan uji $t_{\text {test }}$ posttest kelas Eksperimen

Tabel 11. Uji t test Postest Kelas Eksperimen dan Kelas Kontrol

\begin{tabular}{cccccc}
\hline $\begin{array}{c}\text { Mean } \\
\text { Eksperimen }\end{array}$ & $\begin{array}{c}\text { Mean } \\
\text { Kontrol }\end{array}$ & $\mathbf{t}_{\text {hitung }}$ & $\mathbf{t}_{\text {tabel }}$ & Kriteria & Ket \\
\hline $\mathbf{8 2 , 8 0}$ & 76,15 & 2,3539 & 2,0243 & $t_{\text {hitung }}>\mathrm{t}_{\text {tabel }}$ & $\mathrm{H}_{0}$ ditolak \\
\hline
\end{tabular}

\section{b. Uji $t_{\text {test }}$ Kemampuan Berpikir Kreatif}

1) Uji $t_{\text {test }}$ Kemampuan Berpikir Kreatif Sebelum Perlakuan Kelas Eksperimen dan Kelas Kontrol. Berikut hasil perhitungan uji $t_{\text {test }}$ kemampuan berpikir kreatif sebelum perlakuan.

Tabel 12. Uji t Kemampuan Berpikir Kreatif

\begin{tabular}{cccccc}
\hline Mean Eksperimen & $\begin{array}{c}\text { Mean } \\
\text { Kontrol }\end{array}$ & $\mathbf{t}_{\text {hitung }}$ & $\mathbf{t}_{\text {tabel }}$ & Kriteria & Ket \\
\hline 65,75 & 66,50 & 0,2895 & 2,0243 & $\mathrm{t}_{\text {hitung }}<\mathrm{t}_{\text {tabel }}$ & $\mathrm{H}_{0}$ diterima \\
\hline
\end{tabular}

2) Uji $t_{\text {test }}$ Kemampuan Berpikir Kreatif Sebelum Perlakuan dan Setelah Perlakuan Kelas Kontrol. Berikut hasil perhitungan uji $t_{\text {test }}$ kemampuan berpikir kreatif sebelum dan sesudah perlakuan.

Tabel 13. Uji t Kemampuan Berpikir Kreatif Sebelum dan Setelah Perlakuan Kelas Kontrol

\begin{tabular}{cccccc}
\hline $\begin{array}{c}\text { Mean } \\
\text { Sebelum }\end{array}$ & Mean Setelah & $\mathbf{t}_{\text {hitung }}$ & $\mathbf{t}_{\text {tabel }}$ & Kriteria & Ket \\
\hline 66,50 & 71,15 & 1,7613 & 2,0243 & $\mathrm{t}_{\text {hitung }}<\mathrm{t}_{\text {tabel }}$ & $\mathrm{H}_{0}$ diterima \\
\hline
\end{tabular}

3) Uji $t_{\text {test }}$ Kemampuan Berpikir Kreatif Sebelum Perlakuan dan Setelah Perlakuan Kelas Eksperimen 
Jurnal Mimbar IImu, Vol. 24 No. 3, 2019

P-ISSN: 1829-877X E-ISSN : 2685-9033

Tabel 14. Uji $t_{\text {test }}$ Kemampuan Berpikir Kreatif Sebelum dan Setelah Perlakuan Kelas Eksperimen

\begin{tabular}{cccccc}
\hline Mean Sebelum & $\begin{array}{c}\text { Mean } \\
\text { Setelah }\end{array}$ & $\mathbf{t}_{\text {hitung }}$ & $\mathbf{t}_{\text {tabel }}$ & Kriteria & Ket \\
\hline 65,75 & 77,55 & 4,3719 & 2,0243 & $\mathrm{t}_{\text {hitung }}<\mathrm{t}_{\text {tabel }}$ & $\mathrm{H}_{0}$ diterima \\
\hline
\end{tabular}

4) Uji test Kemampuan Berpikir Kreatif Setelah Perlakuan Kelas Eksperimen dan Kelas Kontrol

Tabel 15. Uji t test Kemampuan Berpikir Kreatif

\begin{tabular}{cccccc}
\hline $\begin{array}{c}\text { Mean } \\
\text { Eksperimen }\end{array}$ & $\begin{array}{c}\text { Mean } \\
\text { Kontrol }\end{array}$ & $\mathbf{t}_{\text {hitung }}$ & $\mathbf{t}_{\text {tabel }}$ & Kriteria & Ket \\
\hline $\mathbf{7 7 , 5 5}$ & 71,15 & 2,3340 & 2,0243 & $\mathrm{t}_{\text {hitung }}<\mathrm{t}_{\text {tabel }}$ & $\mathrm{H}_{0}$ diterima \\
\hline
\end{tabular}

Metode penelitian ini termasuk ke dalam Quasi Experiment dengan menggunakan Pretest-Postest Control Group Design yang menggunakan model pembelajaran Numbered Heads Together (NHT) berbantu media monopoli pada subtema Hebatnya Cita-Citaku terhadap kelas IV terhadap hasil belajar dan kemampuan berpikir kreatif siswa. Menurut Arifin (2009:118), tes merupakan suatu teknik atau cara yang digunakan dalam rangka melaksanakan kegiatan pengukuran, yang di dalamnya terdapat berbagai pertanyaan pernyataan, atau serangkaian tugas yang harus dikerjakan maupun dijawab oleh peserta didik. Berdasarkan hasil analisis Pretest dan Postest hasil belajar ketuntasan belajar siswa dinyatakan jika siswa sudah mencapai batas KKM yang telah ditentukan yaitu 70 (KKM SDN Mranggen 04).

Hasil data kemampuan berpikir kreatif sebelum mendapatkan perlakuan pada kelas eksperimen diperoleh rata-rata 65,75 sedangkan rata-rata pada kelas kontrol diperoleh 66,5. Setelah perlakuan dengan menggunakan model pembelajaran Numbered Heads Together (NHT) berbantu media monopoli terdapat perbedaan hasil pada rata-rata nilai kemampuan berpikir kreatif siswa antara kelas eksperimen dan kelas kontrol. Peningkatan kemampuan berpikir kreatif kelas eksperimen lebih tinggi dengan rata-rata 77,55 dibandingkan dengan kelas kontrol dengan rata-rata 71,15. Berdasarkan analisis data, dapat disimpulkan bahwa kondisi awal sebelum dilaksanakan pembelajaran kelas kontrol dan kelas eksperimen memiliki kemampuan berpikir yang seimbang. Setelah dilaksanakan pembelajaran menggunakan model pembelajaran Numbered Heads Together (NHT) berbantu media monopoli pada kelas eksperimen dan model pembelajaran konvensional pada kelas kontrol menunjukkan perbedaan yang signifikan. Perolehan data kemampuan berpikir kreatif sesuai dengan indikator masingmasing seperti Fluency, Flexibility, Originality, Elaboration, Evaluation (Munandar dalam Susanto: 2013). Data yang diperoleh sebelumnya telah berdistribusi normal dan homogen sehingga analisis data $t_{\text {test }}$ dapat digunakan.

Demi kemudahan dalam menganalisis data untuk menguji hipotesis, maka peneliti menggunakan program Microsoft Excel. Perhitungan $t_{\text {test }}$ dengan nilai $t_{\text {tabel }} 2,0243$ dilakukan sebanyak empat kali yakni uji $t_{\text {test }}$ kemampuan berpikir kreatif sebelum mendapat perlakuan di kelas eksperimen dan kelas kontrol mendapatkan hasil rata-rata 65,75 pada kelas eksperimen dan 66,50 pada rata-rata kelas kontrol dengan $t_{\text {hitung }} 0,2895$, uji $t_{\text {test }}$ kemampuan berpikir kreatif sebelum mendapat perlakuan dan setelah mendapat perlakuan di kelas kontrol mendapatkan hasil rata-rata sebelum 66,50 dan rata-rata 71,15 setelah perlakuan dengan $t_{\text {hitung }} 1,7613$, uji $t_{\text {test }}$ kemampuan berpikir kreatif sebelum mendapat perlakuan dan setelah mendapat perlakuan di kelas eksperimen dengan hasil rata-rata sebelum 65,75 dan rata-rata setelah perlakuan 77,55 dengan hasil $t_{\text {hitung }} 4,3719$, dan yang terakhir uji $t_{\text {test }}$ kemampuan berpikir kreatif setelah mendapatkan perlakuan di kelas eksperimen dan kelas kontrol hasil rata-rata 77,55 kelas eksperimen dan rata-rata 71,15 kelas kontrol dengan $t_{\text {hitung }}$ 2,3340. Berdasarkan data yang diperoleh kelas eksperimen dengan penerapan model pembelajaran Numbered Heads 
Together (NHT) berbantu media monopoli memperoleh hasil lebih tinggi dibandingkan dengan kelas kontrol. Monopoli adalah satu permainan papan dan pemain berlomba untuk mengumpulkan kekayaan melalui satu pelaksanaan sistem permainan dengan memasukan petak pertanyaan yang akan dijawab oleh peserta permainan (Wulandari:2012).

\section{Simpulan dan Saran}

Berdasarkan hasil penelitian yang dilakukan dapat disimpulkan bahwa terdapat pengaruh pada model pembelajaran Numbered Heads Together (NHT) berbantu media monopoli terhadap kemampuan berpikir kreatif siswa dan hasil belajar siswa kelas IV subtema cita-citaku SDN Mranggen 04, hal tersebut dapat ditunjukkan oleh : 1) Ada pengaruh model pembelajaran Numbered Heads Together (NHT) berbantu media monopoli terhadap kemampuan berpikir kreatif siswa kelas IV subtema cita-citaku di SDN Mranggen 04. Hal ini dibuktikan dari $t_{\text {hitung }}=2,3340$ dengan $t_{\text {tabel }}=2,0243$. Untuk $H_{a}$ diterima jika $t_{\text {hitung }} \geq t_{\text {tabel }}$ karena $t_{\text {hitung }}=2,3340>t_{\text {tabel }}=2,0243$. Maka $\mathrm{H}_{0}$ ditolak dan $\mathrm{H}_{\mathrm{a}}$ diterima. Hal ini berarti bahwa ada perbedaan kemampuan berpikir kreatif siswa yang signifikan antara rata-rata kemampuan berpikir kreatif setelah perlakuan di kelas eksperimen dan kelas kontrol. 2) Ada pengaruh pengaruh model pembelajaran Numbered Heads Together (NHT) berbantu media monopoli terhadap hasil belajar siswa kelas IV subtema cita-citaku di SDN Mranggen 04. Hal ini dibuktikan dari $t_{\text {hitung }}=2,3539$ dengan $t_{\text {tabel }}=2,0243$. Untuk $H_{a}$ diterima jika $t_{\text {hitung }} \geq t_{\text {tabel }}$ karena $t_{\text {hitung }}=2,3539>t_{\text {tabel }}=2,0243$. Maka $\mathrm{H}_{0}$ ditolak dan $\mathrm{H}_{\mathrm{a}}$ diterima. Hal ini berarti bahwa ada perbedaan hasil belajar siswa yang signifikan antara rata-rata postest dikelas eksperimen dan kelas kontrol.

\section{Daftar Pustaka}

Anitah . Strategi Pembelajaran di SD.Jakarta:Universitas Terbuka, 2009.

Arikunto, Suharsimi. 2010. Manajemen Penelitian. Jakarta: PT Rineka Cipta.

Arikunto, Suharsimi. 2013. Dasar-Dasar Evaluasi pendidikan. Jakarta: Rineka Cipta.

Arsyad, Azhar. 2016. Media Pembelajaran. Jakarta: PT Raja Grafindo Persada.

Aunurrohman. 2009. Belajar dan Pembelajaran . Bandung: PT Remaja Rosdakarya

Djamarah, Syaiful Bahri dan Zain, Aswan. 2010. Strategi Belajar Mengajar. Jakarta: Rineka Cipta.

Hamdayama, Jumanta. 2015. Model dan Metode Pembelajaran Kreatif dan Berkarakter. Jakarta: Ghalia Indonesia.

Huda, Miftahul. 2013. Model-model Pengajaran dan Pembelajaran. Yogyakarta: Pusataka Belajar.

Huda, Miftahul. 2014. Model-model Pengajaran dan Pembelajaran. Yogyakarta:Pustaka Belajar

Shoimin, Aris. 2014. 68 Model Pembelajaran Inovatif dalam Kurikulum 2013. Yogyakarta: ArRuzz Media.

Slameto. 2010. Belajar \& Faktor-faktor yang Mempengaruhinya. Jakarta: Rineka Cipta.

Sugiyono. 2015. Metode Penelitian Pendidikan. Bandung: Alfabeta. 
Sugiyono. (2016). Metode Penelitian Pendidikan Pendekatan Kuantitatif, Kualitatif, dan R\&D. Bandung: Alfabeta.

UU Sisdiknas No. 20 Tahun 2003, Pasal 1 ayat 19

Sudarma, Momon. 2013. Mengembangkan Keterampilan Berpikir Kreatif. Jakarta: PT. Raja Grafindo Persada.

Rakhmat, Jalaluddin. 2013. PsikologiKomunikasi. Bandung: RemajaRosdakarya.

Tawil, Muh dan Kemala Suryasari. 2012. Implementasi Model Pembelajaran Fisika BerbasisPortofolio untuk Meningkatkan Keterampilan Berpikir Kreatif. Makassar: Universitas Negeri Makassar, ISSN 1411-2531.

https://www.gurusukses.com/mengelola-pembelajaran-berdasarkan-permendikbud 22-tahun2016. Di Unduh pada 16 Juli 2018

https://www.nidokna.com/2017/04/melestarikan-hewan-dan-tumbuhan-langka.html. Di Unduh pada 13 Agustus 2018

https://nasional.kompas.com/read/2012/12/14/02344589/twitter.com?page=all. Diunduh pada 07 Oktober 2019 